\title{
Diyabetli Bireylerde Sağlık Okuryazarlığı ve Akılcı İlaç Kullanımı Arasındaki İlişki
}

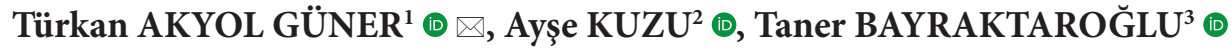 \\ ${ }^{1}$ Zonguldak Bülent Ecevit Üniversitesi, Sağlık Bilimleri Fakültesi Sosyal Hizmet Bölümü, Kozlu, Zonguldak, Türkiye \\ ${ }^{2}$ Zonguldak Bülent Ecevit Üniversitesi, Ahmet Erdoğan Sağlık Hizmetleri Meslek Yüksekokulu, Tibbi Hizmetler ve Teknikler Bölümü Kozlu, \\ Zonguldak, Türkiye \\ ${ }^{3}$ Zonguldak Bülent Ecevit Üniversitesi, Tip Fakültesi, Endokrinoloji ve Metabolizma Hastalıkları Anabilim Dalı, Zonguldak, Türkiye
}

Bu makaleye yapılacak atıf: Akyol Güner T, Kuzu A, Bayraktaroğlu T. Diyabetli Bireylerde Sağlık Okuryazarlığı ve Akılcı İlaç Kullanımı Arasındaki İlişki. Türk Diyab Obez 2020;3: 214-223.

\begin{abstract}
ÖZ
Amaç: Sağlık okuryazarlığı, kronik hastalık yönetiminin etkili yapılabilmesi için oldukça önemlidir. Bu çalışma, diyabetli bireylerde sağlık okuryazarlığı ve akılcı ilaç kullanımı arasındaki ilişkiyi incelemek amacıyla yapılmıştır.

Gereç ve Yöntemler: Tanımlayıcı ve kesitsel tipteki bu çalışma, 24 Ocak - 5 Mart 2020 tarihleri arasında Zonguldak Merkez'de bulunan Zonguldak Diyabet Derneği'nde dahil edilme kriterlerini karşılayan ve çalışmaya katılmaya gönüllü 220 diyabetli birey ile tamamlanmıştır. Çalışmanın verileri, sosyo-demografik ve sağlığa ilişkin özellikler formu, Türkiye Sağlık Okuryazarlığı Ölçeği (TSYO32) ve Akılcı İlaç Kullanımı Ölçeği ile yüz yüze görüşme yöntemiyle toplanmıştır.

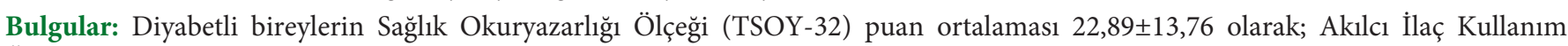

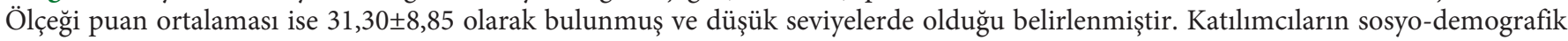
özelliklerine göre sağlık okuryazarlı̆̆ı ve akılcı ilaç kullanım düzeylerinin karşılaştırılması yapıldığında; cinsiyetine, yaşına, eğitim durumuna, medeni durumuna ve gelir durumuna göre sağılı okuryazarlı̆̆ı ve akılcı ilaç kullanım düzeylerinin istatistiksel olarak anlamlı farklılık gösterdiği belirlenmiştir $(\mathrm{p}<0,001)$. Diyabetli bireylerin sağlık ile ilgili özelliklerine göre sağlık okuryazarlığı ve akılcı ilaç kullanım düzeylerinin karşılaştırılması yapıldığında ise; diyabet tanı süresine, başka kronik hastalık durumuna, düzenli doktor kontrolüne, diyabet eğitimi alma ve eğitim gereksinimi durumuna, ilaçlarını düzenli alma ve reçete dışı ilaç kullanma durumuna göre istatistiksel olarak anlamlı farklılıklar gösterdiği görülmüştür $(\mathrm{p}<0,001)$. Diyabetli bireylerde sağlık okuryazarlığ ile akılcı ilaç kullanımı düzeyleri arasındaki ilişki incelendiğinde ise pozitif yönlü ve yüksek düzeyde anlamlı bir ilişki olduğu belirlenmiştir $(r=0,827 ; \mathrm{p}<0,001)$. Sonuç: Diyabetli bireylerin sağlık okuryazarlık düzeyinin ve akılcı ilaç kullanımın yetersiz düzeyde olduğu belirlenmiştir. Sağlık okuryazarlık düzeyinin yeterli olması ile akılcı ilaç kullanımı ve tedavi uyumunun sağlanmasının daha kolay olacağı bilindiğinden, diyabetli bireyler sağlık okuryazarlık düzeylerinin geliştirilmesi konusunda desteklenmelidir.
\end{abstract}

Anahtar Sözcükler: Diyabet, Sağlık okuryazarlı̆̆ı, Akılcı ilaç kullanımı

\section{The Relationship Between Health Literacy and Rational Drug Use in Individuals with Diabetes}

\begin{abstract}
Aim: Health literacy is very important to manage a chronic disease effectively. This study was conducted to examine the relationship between health literacy and rational drug use in individuals with diabetes.

Material and Methods: This descriptive and cross-sectional study was conducted on 220 diabetic individuals/patients who met the criteria and volunteered to participate between January 24 and March 52020 in Zonguldak Diabetes Association located in Zonguldak. The data were collected by face-to-face interview technique through the socio-demographic and health characteristics form, Turkish Health Literacy Scale (THLS-32) and Rational Drug Use Scale.
\end{abstract}

ORCID: Türkan Akyol / Güner 0000-0003-0138-0669, Ayşe Kuzu / 0000-0003-0181-8747, Taner Bayraktaroğlu / 0000-0003-3159-6663 
Results: The Health Literacy Scale (THLS-32) average score of individuals with diabetes was found 22.89 \pm 13.76 ; The Rational Drug Use Scale score average was found $31.30 \pm 8.85$ and it was determined that both health literacy and rational drug use levels were low. When the health literacy and rational drug use levels of the participants were compared according to their socio-demographic characteristics, it has been determined that there is a statistically significant difference in health literacy and rational drug use levels according to gender, age, education, marital status and income $(\mathrm{p}<0.001)$. When the health literacy and rational drug use levels of individuals with diabetes were compared according to their health characteristics; it was observed that there were statistically significant differences according to the duration of diabetes diagnosis, other chronic disease status, regular physician control, diabetes education or training requirement, regular drug use and non-prescription drug use $(\mathrm{p}<0.001)$. When the relationship between health literacy and rational drug use in individuals with diabetes was examined, it was determined that there was a positive and highly significant relationship $(\mathrm{r}=0.827 ; \mathrm{p}<0.001)$.

Conclusion: It was determined that the health literacy level and rational drug use level of individuals with diabetes were insufficient. Since it is known that rational drug use and treatment compliance will be easier with a sufficient level of health literacy, individuals with diabetes should be supported in improving their health literacy level.

Key Words: Diabetes, Health literacy, Rational drug use

\section{Gíriș}

Sağlık okuryazarlığı (SOY), bir kronik hastalık yönetiminin etkili yapılabilmesi için oldukça önemli bir faktördür (1-3). Sağlık okuryazarlığının yetersiz olması, kişinin kendi sağlı̆̆1 ve öz yönetimine katılım oranlarının azalmasına, tıbbi koşulların kötüleşmesine, hastane yatışlarında artışa, ilaç uyumunda sorunlar yaşanmasına, sağlık maliyetlerinde artışa ve dolayısıyla mortalite ve morbidite oranlarında artışa neden olur (4-6). Türkiye'de ve Dünya'da sağlık okuryazarlığını farklı gruplarda değerlendiren çalışmalar yapilmış olup bu çalışmaların çoğu sağlık okuryazarlı̆̆ının yetersiz seviyelerde olduğunu ve geliştirilmesi için girişimler yapılması gerektiğini bildirmektedir (7-11). Türkiye'de SOY düzeyinin ölçülmesini amaçlayan Türkiye Sağlı Okuryazarlığı Çalışması sonucuna göre de nüfusun yaklaşık \%65’inin "sorunlu ve yetersiz" sağlık okuryazarlığına sahip olduğu belirlenmiştir (10).

Diabetes Mellitus (DM), 21. yüzyılın en hızlı büyüyen sağlık sorunlarından biri olan, bulaşıcı olmayan, kronik, epidemik bir hastalıktır (12). Dünya verilerine bakıldığında; 2000 yılında 151 milyon olan diyabetli birey sayısı (13), 2018 yılında ise 463 milyona ulaşmış ve prevalansı \%9,3'e yükselmiştir. Bu artışın hız kesmeden süreceği, 2030 yılında diyabetli sayısının 578 milyona, 2045 yllında ise 700 milyona yükseleceği öngörülmektedir. Türkiye'de de diyabet prevelansı dünya verileri ile benzerlik göstermekte olup yapılan en büyük saha çalışması olan Türkiye Diyabet Epidemiyolojisi Çalışması (TURDEP-I ve II) sonuçlarına göre, 19982010 yılları arasında Türk toplumunda diyabet sıklı̆̆ $\% 90$ artarak, prevelansının \%7.7'den \%13.7'ye çıktığı bildirilmiş$\operatorname{tir}(14)$.

Diyabetli bireylerde görülen akut ve kronik komplikasyonlar geri dönüşü olmayan ciddi sağlık sorunlarına yol açtığı için, hastalığın önlenmesi ve kontrolü acil bir halk sağlığı önceliği olarak kabul edilmektedir (15). Bu komplikasyonların önlenebilmesi ya da geciktirilebilmesi için ise bireyin hastalık yönetimini en doğru şekilde yapabilmesi son derece önemlidir (16). Diyabetli bireylerin hastalıklarını etkili bir şekilde yönetebilmeleri için sağlık profesyonellerinden, tedavinin temel taşı olduğu bildirilen diyabet eğitimi almaları ve verilen eğitim talimatlarını anlamaları gerektiği bildirilmektedir $(12,17)$. Bireylerin bu eğitim talimatlarını anlaması ve sağlık ile ilgili karmaşık konularda sahip olduğu bilgi ve yeterlilik ise sağlık okuryazarlığı (SOY) olarak bilinir (18). Günümüzde önemi giderek artan SOY; "kişiye tıbbi bir bilgi sunulduğunda, kişinin bu bilgiyi anlayip yorumlayabilmesi ve buna uygun davranabilmesi" olarak ifade edilmektedir(19). SOY ayrıca, bireylerin sağlıkları ile ilgili bilgileri okumayı, sözel olarak verilen iletileri anlamayı, her konuda mantıklı bir şekilde eleştirel gözle bakarak karar vermeyi ve bu kararları uygulayabilme bilgi ve becerisini içermektedir (20).

Diyabetli bireyler içinde de oldukça önemli olan sağllk okuryazarlığının, yapılan ilgili çalışma sonuçlarında düşük seviyelerde olduğu bildirilmiş $(4,17,21-26)$, yeterli SOY sahip olan bireylerin ilaç kullanım talimatlarını daha iyi anlayıp hastalık yönetimini ve tedaviye uyumu daha kolay sağlayabildikleri belirlenmiştir (17,23,27-30). Tedaviye uyum, bireye reçete edilen tedavinin önerilen şekliyle, uygun zaman ve dozda alınması ve tedavi için belirlenen süreçte devamlılığın sağlanması kısaca kullanılması gereken ilaçların akılcı şekilde kullanılması anlamına gelmektedir (31). Akılcı İlaç Kullanımı (AİK) ise, "Hastaların ilaçları klinik ihtiyaçlarına uygun şekilde, uygun süre ve kişisel gereksinimlerini karşılayacak dozlarda, kendilerine ve topluma en düşük maliyette almalarını sağlayan kurallar bütünü” olarak tanımlanmış olup (32), tüm dünyada kullanılan ilaçların \%50'sinden fazlasının insanlar tarafından akılcı șekilde kullanılmadığı bildirilmiştir(33). 
İlaç kullanım alışkanlıkları, bireyin sosyo-demografik özelliklerinin yanı sıra ilacın doğru kullanılmasını sağlayan sağlık okuryazarlığı düzeyinden de önemli oranda etkilenmektedir (30,34). Diyabette sağlık okuryazarlığı, özellikle insülin dozlarını anlama ve ayarlayabilme, kullandığı araç ve gereçleri bilme, kan şekeri sonucunu yorumlama, insülin ya da oral antidiyabetik gibi ciddi ilaçların kullanımını yönetebilme ile ilaç yönergelerini takip edebilme açısından son derece önemlidir (25). Yapılan çalışmalarda diyabetli bireylerde ilaç kullanım sorunlarının yaygın olarak görüldüğü (35), diyabette ilaç kullanımını etkileyen en önemli etmenlerden birinin sağlık okuryazarlığı olacağı bildirilmiş$\operatorname{tir}(36)$.

Bu yönüyle sağlik okuryazarlığı diyabette ilaç kontrolünün ve akılcı ilaç kullanımının sağlanabilmesi için vazgeçilmez bir unsur olarak ortaya çıkmaktadır. Ancak, diyabetli bireylerin, akılcı ilaç kullanım düzeyini ve kullanılan ilaçları ile ilgili bilgi, tutum ve davranışlarını belirleyen, ülkemize özgü verileri yansıtacak araştırmaların yetersiz sayıda olduğu ve yapılmasının gerekli olduğu bildirilmektedir(37). Bu gerekçelerle planladığımız çalışmada, diyabetli bireylerde sağlık okuryazarlığı ve akılcı ilaç kullanımı arasındaki ilişkinin incelenmesi amaçlanmıştır.

\section{GEREÇ ve YÖNTEMLER}

Tanımlayıcı ve kesitsel tipteki bu çalışma, 24 Ocak- 5 Mart 2020 tarihleri arasında Zonguldak ilinde faaliyetlerde bulunan Zonguldak Kronik Hastalıklar ve Diyabet Derneği'nde yapılmıştır. Diyabet derneğine kayıtlı 238 diyabetli üye vardı. Dahil edilme kriterlerini karşılayan ve çalışmaya katılmaya gönüllü diyabetik 220 olgu ile çalışma tamamlanmıştır. Çalışmaya, diyabet tanısı alan, görme, işitme, bilişsel ve mental sorunu olmayan, 65 yaş üzeri Standardize Mini Mental Test'ten 23 puan ve üzerinde alan, Türkçe okuma yazma bilen ve çalışmaya katılmaya gönüllü bireyler dâhil edilmiştir. Çalışmanın verileri araştırmacı (T.A.G.) tarafindan dernekte eğitim odası olarak kullanılan uygun bir ortamda yüz yüze görüşme yoluyla toplanmıştır.

\section{Veri Toplama Araçları}

Sosyo-demografik ve sağlığa ilişkin veriler, araştırmacılar tarafindan hazırlanan 13 sorudan oluşan bir "Sosyo-Demografi ve Sağlık Anket Formu” ile toplandı. Bu ankette, yaş, cinsiyet, eğitim, medeni durum, çalışma durumu, ekonomik durumu, diyabet tanı süresi, başka bir kronik hastalığın varlığı, düzenli doktor kontrolü, diyabet eğitimi durumu, ilaçlarını düzenli alma durumu ve reçetesiz ilaç kullanım durumunu sorgulayan sorular yer almaktadır.

Türkiye Sağlık Okuryazarlığı Ölçeği (TSOY-32): Avrupa Sağlık Okuryazarlığı Araştırma Konsorsiyumu tarafından geliştirilen kavramsal çerçeveye dayanan Türkiye Sağllk Okuryazarlığ Ölçeği (TSOY-32), okuryazar olan kişilerde sağlık okuryazarlığını değerlendirmek amacıyla geliştirilmiştir. "Her madde $1=$ Çok kolay, $2=$ Kolay, $3=$ Zor, $4=$ Çok zor olacak şekilde dört derecelidir." Puan hesaplarına geçilmeden önce, kodlar 1-4, 4-1 olacak şekilde yeniden kodlanarak, formül yardımıyla hesaplama yapılmaktadır. Sağlık okuryazarlığ 1 düzeyi, elde edilen puana göre dört kategoride değerlendirilmiştir:

I. 0-25 puan: yetersiz sağlık okuryazarlığ

II. >25-33 puan: sorunlu - sinırlı sağlık okuryazarlığ

III. >33-42 puan: yeterli sağlık okuryazarllğ

IV. $>42-50$ puan: mükemmel sağlık okuryazarlığıdır.

Ölçek için gerekli kullanım şartları sağlanmıştır. Ölçeğin Crohnbach's alfa değeri 0,92 olarak saptanmıștır (38). Ölçeğin çalışmamızda kullanımı sonucunda Crohnbach's alfa değeri 0,91 olarak bulunmuştur.

Akılcı İlaç Kullanımı Ölçeği: Akılcı ilaç kullanımını değerlendiren 21 sorudan oluşan bu ölçek, Demirtaş ve ark. tarafından (2018) geliştirilmiştir. "Ölçeğe verilen cevaplar Evet: 2 puan, Bilmiyorum: 1 puan, Hayır: 0 puan şeklinde puanlanmaktadır. Ölçek için kestirim değeri 34 puan olup, 35 puan ve üzeri alan bireyler akılcı ilaç kullanımı bilgisine sahip olarak değerlendirilir." Ölçeğin Crohnbach's alfa değeri 0,78 olarak saptanmıştır (39). Ölçeğin çalışmamızda kullanımı sonucunda Crohnbach's alfa değeri 0,81 olarak bulunmuştur.

\section{İstatistiksel Analiz}

Verilerin istatistiksel analizi SPSS 22.0 (IBM Corporation, Armonk, NY, ABD) paket programı kullanılarak yapılmıştır. Tanımlayıcı istatistikler frekans ve yüzde ile, değişkenlerin ölçek puanlarına göre dağılımı ise median (minimum-maksimum) değerleri ile gösterilmiştir. Verilerin normal dağ1lıma uygunluğu Shapiro-Wilk testi ile değerlendirilmiş ve normal dağılım göstermediği belirlenmiştir. Normal dağ1lıma uymayan değişkenlerin karşılaştırılmasında non-parametrik testlerden Mann-Whitney U ve Kruskal-Wallis testi kullanılmıştır. İkiden fazla gruplu değişkenlerde farklılıkları belirlemek amaciyla Post-Hoc testlerden Dunn-Bonferroni testi kullanılmıştır. Diyabetli bireylerde sağlık okuryazarlığı ile akılcı ilaç kullanımı arasındaki ilişki Spearman Korelasyon Katsayısı ile belirlenmiştir. Testlerde anlamlılık düzeyi $p<0,05$ olarak alınmıştır.

\section{Etik İlkeler}

Çalışmanın yapılabilmesi için Zonguldak Bülent Ecevit Üniversitesi İnsan Araştırmaları Etik Kurulu'ndan 22.01.2020/723 tarih ve protokol numarası ile gerekli etik 
kurul onayı ve Diyabet Derneği başkanından gerekli kurum izni yazılı ve imzalı olarak alınmıştır. Ayrıca çalışmaya katılan tüm diyabetik olgulara çalışma hakkında bilgi verilerek sözlü ve yazılı onamları alınmıştır.

\section{BULGULAR}

Araştırma kapsamındaki diyabetli bireylerin sosyo-demografik ve sağlık özelliklerine ilişkin veriler Tablo $1 \mathrm{~A}$ ve 1B'de verilmiştir. Katılımcıların demografik özellikleri incelendiğinde; \%56,8'inin 58-67 yaş grubunda olduğu, \%82,7'sinin erkek olduğu, \% 78,6'sının evli olduğu ve çoğunluğunun $(\% 64,5)$ gelir durumunun orta düzeyde olduğu belirlenmiştir. Katılımcıların sağlık özelliklerine ilişkin veriler incelendiğinde ise; \% 40,5'inin diyabet tanı süresinin 6-10

Tablo 1A: Diyabetik olguların sosyo-demografik özelliklerine göre dağılımı.

\begin{tabular}{lc}
\hline $\begin{array}{l}\text { Sosyo-Demografik } \\
\text { Özellikler }\end{array}$ & $\begin{array}{c}\text { Olgu Sayısı } \\
\text { n (\%) }\end{array}$ \\
\hline Yaş grubu & $33(15,0)$ \\
\hline $48-57$ yll & $125(56,8)$ \\
\hline $58-67$ yıl & $62(28,2)$ \\
\hline$\geq 68$ yıl & $38(17,3)$ \\
\hline Cinsiyet & $182(82,7)$ \\
\hline Kadın & \\
\hline Erkek & $61(27,7)$ \\
\hline Ĕ̈itim Durumu & $54(24,5)$ \\
\hline İlkokul & $70(31,8)$ \\
\hline Ortaokul & $35(15,9)$ \\
\hline Lise & \\
\hline Üniversite & $173(78,6)$ \\
\hline Medeni durum & $9(4,1)$ \\
\hline Evli & $38(17,3)$ \\
\hline Bekâr & \\
\hline Dul & $125(56,8)$ \\
\hline Çalışma Durumu & $95(43,2)$ \\
\hline Çalı̧mı̀or & \\
\hline Çalışıor & $142(64,5)$ \\
\hline Gelir Durumu & \\
\hline İyi & \\
\hline Orta & \\
\hline
\end{tabular}

yll arasında olduğu, \%69,0'ının tip 2 diyabetli olduğu, \% 58,6'sının diyabet ile birlikte başka bir kronik hastalığa sahip olduğu, \% 79,1'inin diyabet ile ilgili eğitim gereksinimi olduğu ve büyük çoğunluğunun ilaçlarını düzenli aldığg $1 \% 85,5)$ belirlenmiştir.

Katılımcıların Sağlık Okuryazarlığı Ölçeği (TSOY-32) puan ortalaması 22,89 $\pm 13,76$ olarak belirlenmiş olup, büyük çoğunluğunun $(\% 56,4)$ yetersiz sağlık okuryazarlığ gorisinde olduğu görülmüştür. Katılımcıların Akılcı İlaç Kullanım Ölçeği puan ortalaması ise $31,30 \pm 8,85$ olarak bulunmuş ve ölçeğin kestirim değerine göre (34 puan) çalışmaya katılan diyabetli bireylerin akılcı ilaç kullanımın düşük düzeyde olduğu belirlenmiştir (Tablo 2).

Tablo 1B: Diyabetik olguların sağlık özelliklerine göre dağılımı.

\begin{tabular}{|c|c|}
\hline Sağlık Özellikleri & $\begin{array}{c}\text { Olgu Sayısı } \\
\text { n (\%) }\end{array}$ \\
\hline \multicolumn{2}{|c|}{ Diyabet Tanı Süresi } \\
\hline$\leq 5 \mathrm{yll}$ & $49(22,3)$ \\
\hline $6-10$ yıl & $89(40,5)$ \\
\hline $11-15 \mathrm{yll}$ & $72(32,7)$ \\
\hline$\geq 15$ yll & $10(4,5)$ \\
\hline \multicolumn{2}{|l|}{ Diyabet Tipi } \\
\hline Tip 1 & $68(31,0)$ \\
\hline Tip 2 & $152(69,0)$ \\
\hline \multicolumn{2}{|c|}{ Başka Kronik Hastalık Durumu } \\
\hline Evet & $129(58,6)$ \\
\hline Hayır & $91(41,4)$ \\
\hline \multicolumn{2}{|c|}{ Düzenli Doktor Kontrolü } \\
\hline Evet & $131(59,5)$ \\
\hline Hayır & $89(40,5)$ \\
\hline \multicolumn{2}{|c|}{ Diyabet Eğitimi Alma } \\
\hline Evet & $89(40,5)$ \\
\hline Hayır & $131(59,5)$ \\
\hline \multicolumn{2}{|c|}{ Diyabet Eğitimi Gereksinimi } \\
\hline Evet & $174(79,1)$ \\
\hline Hayır & $46(20,9)$ \\
\hline \multicolumn{2}{|c|}{ İlaçlarını Düzenli Alma } \\
\hline Evet & $188(85,5)$ \\
\hline Hayır & $32(14,5)$ \\
\hline \multicolumn{2}{|c|}{ Reçete Dışı İlaç Kullanma } \\
\hline Evet & $39(17,7)$ \\
\hline Hayır & $181(82,3)$ \\
\hline
\end{tabular}


Tablo 3'de diyabetli bireylerin demografik özelliklerine göre sağlık okuryazarlı̆̆ı ve akılcı ilaç kullanım düzeylerinin karşılaştırılması yer almaktadır. Tabloya göre katılımcıların cinsiyetine, yaşına, eğitim durumuna, medeni durumuna ve gelir durumuna göre sağlık okuryazarlığı ve akılcı ilaç kullanım düzeylerinin istatistiksel olarak anlamlı farklılık göster- diği belirlenmiştir ( $\mathrm{p}<0,001)$. Yapılan ileri analize göre, 48-57 yaş grubunda olanların, eğitim durumunu lise ve üniversite olarak belirtenlerin ve medeni durumunu evli olarak belirtenlerin sağlık okuryazarlığı ve akılcı ilaç kullanımı ölçek puanlarının daha yüksek olduğu belirlenmiştir (Tablo 3).

Tablo 2: Diyabetik olguların ölçek puan ortalamaları.

\begin{tabular}{|c|c|c|c|}
\hline \multirow{2}{*}{ TSOY-32 Ölçeği Kategorileri } & \multirow{2}{*}{$\begin{array}{c}\text { Olgu Sayısı } \\
\text { n (\%) }\end{array}$} & \multicolumn{2}{|c|}{ Ölçek Puanı } \\
\hline & & Ort \pm SS & Min-Mak \\
\hline 1. Yetersiz SOY (0-25 puan) & $124(56,4)$ & $11,91 \pm 6,11$ & $3,65-24,48$ \\
\hline 2. Sorunlu-Sinırlı SOY (26-33 puan) & $30(13,6)$ & $30,36 \pm 2,88$ & $25,52-33,33$ \\
\hline 3. Yeterli SOY (34-42 puan) & $52(23,6)$ & $39,30 \pm 2,30$ & $35,42-41,67$ \\
\hline 4. Mükemmel SOY (43-50 puan) & $14(6,4)$ & $43,11 \pm 0,91$ & $42,19-44,29$ \\
\hline TSOY-32 Ölçeği Toplam Puanı & $220(100)$ & $22,89 \pm 13,76$ & $3,65-44,27$ \\
\hline AİK Ölçeği Toplam Puanı & $220(100)$ & $31,30 \pm 8,85$ & $13,00-42,00$ \\
\hline
\end{tabular}

TSYO: Türkiye Sağlık Okuryazarlığı, AİK: Akılcı İlaç Kullanımı, Min.-Mak.: Minimum-Maksimum Puan.

Tablo 3: Diyabetik olguların demografik özelliklerine göre sağlık okuryazarlığı ve akılcı ilaç kullanımı düzeylerinin karşılaştırılması.

\begin{tabular}{|c|c|c|c|c|c|}
\hline \multirow{2}{*}{$\begin{array}{l}\text { Demografil } \\
\text { Özellikler }\end{array}$} & & \multicolumn{2}{|c|}{$\begin{array}{l}\text { TSOY-32 Ölçeği } \\
\text { Puanları }\end{array}$} & \multicolumn{2}{|l|}{$\begin{array}{l}\text { AİK Ölçeği } \\
\text { Puanları }\end{array}$} \\
\hline & & Medyan(Min.-Max.) & & Medyan(Min.-Max.) & \\
\hline \multirow{3}{*}{ Cinsiyet } & Kadın & $39,06(29,17-42,71)$ & & $41,00(34,00-42,00)$ & \\
\hline & Erkek & $16,66(3,65-44,27)$ & & $27,00(13,00-42,00)$ & \\
\hline & & ${ }^{b} \mathrm{p}<0,001$ & & ${ }^{\mathrm{b}} \mathrm{p}<0,001$ & \\
\hline \multirow{4}{*}{ Yaş } & $48-57 \mathrm{yll}^{1}$ & $35,93(30,73-42,19)$ & \multirow{3}{*}{${ }^{\star} 1-2 ; 2-3 ; 1-3$} & $41,00(40,00-42,00)$ & \multirow{3}{*}{${ }^{\star} 1-2 ; 2-3 ; 1-3$} \\
\hline & $58-67 \mathrm{yll}^{2}$ & $25,52(5,73-44,27)$ & & $34,00(21,00-42,00)$ & \\
\hline & $\geq 68 \mathrm{yll}^{3}$ & $8,33(3,65-16,67)$ & & $21,00(13,00-27,00)$ & \\
\hline & & ${ }^{\mathrm{a}} \mathrm{p}<0,001$ & & ${ }^{\mathrm{a}} \mathrm{p}<0,001$ & \\
\hline \multirow{5}{*}{$\begin{array}{l}\text { Eğitim } \\
\text { Durumu }\end{array}$} & İlkokul $^{1}$ & $8,33(3,65-9,38)$ & \multirow{4}{*}{$\begin{array}{c}{ }^{*} 1-2 ; 1-3 ; 1-4 ; \\
2-3 ; 2-4\end{array}$} & $24,00(13,00-28,00)$ & \multirow{4}{*}{$\begin{array}{c}{ }^{\star} 1-2 ; 1-3 ; 1-4 ; \\
2-3 ; 2-4\end{array}$} \\
\hline & Ortaokul $^{2}$ & $16,66(8,33-24,48)$ & & $25,00(21,00-32,00)$ & \\
\hline & Lise $^{3}$ & $36,97(15,63-44,27)$ & & $41,00(26,00-42,00)$ & \\
\hline & Üniversite $^{4}$ & $41,66(30,73-42,71)$ & & $41,00(40,00-42,00)$ & \\
\hline & & ${ }^{\mathrm{a}} \mathrm{p}<0,001$ & & ${ }^{\mathrm{a}} \mathrm{p}<0,001$ & \\
\hline \multirow{4}{*}{$\begin{array}{l}\text { Medeni } \\
\text { Durum }\end{array}$} & Evli $^{1}$ & $27,60(5,73-44,27)$ & \multirow{3}{*}{${ }^{*} 1-3 ; 2-3$} & $37,00(18,00-42,00)$ & \multirow{3}{*}{${ }^{*} 1-3 ; 2-3$} \\
\hline & Bekar $^{2}$ & $27,00(27,00-41,00)$ & & $27,00(27,00-41,00)$ & \\
\hline & $\mathrm{Dul}^{3}$ & $22,00(13,00-27,00)$ & & $22,00(13,00-27,00)$ & \\
\hline & & ${ }^{\mathrm{a}} \mathrm{p}<0,001$ & & ${ }^{\mathrm{a}} \mathrm{p}<0,001$ & \\
\hline \multirow{3}{*}{$\begin{array}{l}\text { Gelir } \\
\text { Durumu }\end{array}$} & İyi & $41,00(39,00-42,00)$ & & $41,00(39,00-42,00)$ & \\
\hline & Orta & $26,00(13,00-42,00)$ & & $10,41(3,65-41,67)$ & \\
\hline & & ${ }^{\mathrm{b}} \mathrm{p}<0,001$ & & ${ }^{\mathrm{b}} \mathrm{p}<0,001$ & \\
\hline
\end{tabular}

${ }^{\mathrm{a}}$ : Kruskal-Wallis test ${ }^{\mathrm{b}}$ : Mann-Whitney U test ${ }^{\star}$ Dunn Bonferroni

TSYO-32: Türkiye Sağlık Okuryazarlığı-32, AİK: Akılcı İlaç Kullanımı 
Tablo 4: Diyabetli bireylerin sağlık ile ilgili özelliklerine göre sağlık okuryazarlı̆̆ı ve akılcı ilaç kullanım düzeylerinin karşılaştırılması.

\begin{tabular}{|c|c|c|c|c|c|}
\hline \multirow{2}{*}{ Sağlık Özellikleri } & & \multicolumn{2}{|c|}{ TSOY-32 Ölçeği Puanları } & \multicolumn{2}{|c|}{ AİK Ölçeği Puanları } \\
\hline & & $\begin{array}{c}\text { Medyan } \\
\text { (Min.-Max.) } \\
\end{array}$ & & $\begin{array}{c}\text { Medyan } \\
\text { (Min.-Max.) }\end{array}$ & \multirow{5}{*}{$\begin{array}{r}{ }^{\star} 1-2 ; 1-3 ; 1 \\
4 ; 2-3 ; 2-4\end{array}$} \\
\hline \multirow{5}{*}{$\begin{array}{l}\text { Diyabet Tanı } \\
\text { Süresi }\end{array}$} & $<5 \mathrm{yll}^{1}$ & $37,50(29,17-44,27)$ & \multirow{4}{*}{$\begin{array}{l}{ }^{*} 1-2 ; 1-3 ; 1- \\
4 ; 2-3 ; 2-4\end{array}$} & $41,00(39,00-42,00)$ & \\
\hline & $6-10 \mathrm{yll}^{2}$ & $25,52(6,77-42,71)$ & & $34,00(22,00-42,00)$ & \\
\hline & $11-15 \mathrm{yll}^{3}$ & $8,33(5,73-21,88)$ & & $24,50(13,00-28,00)$ & \\
\hline & $\geq 15 \mathrm{yll}^{4}$ & $4,68(3,65-5,73)$ & & $20,50(20,00-21,00)$ & \\
\hline & & ${ }^{\mathrm{a}} \mathrm{p}<0,001$ & & ${ }^{\mathrm{a}} \mathrm{p}<\mathbf{0 , 0 0 1}$ & \\
\hline \multirow{3}{*}{$\begin{array}{l}\text { Başka Kronik } \\
\text { Hastalık Durumu }\end{array}$} & Evet & $8,33(3,65-41,67)$ & & $26,00(13,00-41,00)$ & \\
\hline & Hayır & $36,97(16,67-44,27)$ & & $41,00(22,00-42,00)$ & \\
\hline & & ${ }^{\mathrm{b}} \mathbf{p}<\mathbf{0 , 0 0 1}$ & & ${ }^{\mathrm{b}} \mathrm{p}<0,001$ & \\
\hline \multirow{3}{*}{$\begin{array}{l}\text { Düzenli Doktor } \\
\text { Kontrolü }\end{array}$} & Evet & $35,41(8,33-44,27)$ & & $41,00(22,00-42,00)$ & \\
\hline & Hayır & $8,33(3,65-22,92)$ & & $24,00(13,00-32,00)$ & \\
\hline & & ${ }^{\mathrm{b}} \mathbf{p}<\mathbf{0 , 0 0 1}$ & & ${ }^{b} \mathbf{p}<0,001$ & \\
\hline \multirow{3}{*}{$\begin{array}{l}\text { Diyabet Eğitimi } \\
\text { Alma }\end{array}$} & Evet & $36,97(5,73-42,71)$ & & $41,00(26,00-42,00)$ & \\
\hline & Hayır & $15,62(3,65-44,27)$ & & $25,00(13,00-42,00)$ & \\
\hline & & ${ }^{\mathrm{b}} \mathbf{p}<\mathbf{0 , 0 0 1}$ & & ${ }^{\mathrm{b}} \mathbf{p}<\mathbf{0 , 0 0 1}$ & \\
\hline \multirow{3}{*}{$\begin{array}{l}\text { Diyabet Eğitimi } \\
\text { Gereksinimi }\end{array}$} & Evet & $16,66(3,65-44,27)$ & & $27,00(13,00-42,00)$ & \\
\hline & Hayır & $38,54(29,17-42,19)$ & & $41,00(34,00-42,00)$ & \\
\hline & & ${ }^{\mathrm{b}} \mathbf{p}<\mathbf{0 , 0 0 1}$ & & ${ }^{\mathrm{b}} \mathbf{p}<\mathbf{0 , 0 0 1}$ & \\
\hline \multirow{3}{*}{$\begin{array}{l}\text { İlaçlarını Düzenli } \\
\text { Alma }\end{array}$} & Evet & $25,52(5,73-44,27)$ & & $34,00(21,00-42,00)$ & \\
\hline & Hayır & $8,33(3,65-8,85)$ & & $20,00(13,00-28,00)$ & \\
\hline & & ${ }^{b} \mathbf{p}<0,001$ & & ${ }^{b} \mathbf{p}<0,001$ & \\
\hline \multirow{3}{*}{$\begin{array}{l}\text { Reçete Dışı İlaç } \\
\text { Kullanma }\end{array}$} & Evet & $8,33(3,65-37,50)$ & & $24,00(13,00-41,00)$ & \\
\hline & Hayır & $35,41(8,33-44,27)$ & & $41,00(24,00-42,00)$ & \\
\hline & & ${ }^{\mathrm{b}} \mathrm{p}<0,001$ & & ${ }^{b} \mathbf{p}<0,001$ & \\
\hline
\end{tabular}

${ }^{a}$ : Kruskal-Wallis test ${ }^{b}$ : Mann-Whitney U test ${ }^{\star}$ Dunn Bonferroni

TSYO(32): Türkiye Sağlık Okuryazarlığı Ölçeği, AIKK: Akılcı İlaç Kullanımı Ölçeği

Tablo 5: Sağlık okuryazarlığı ile akılcı ilaç kullanımı ilişkisi.

\begin{tabular}{lcc}
\hline Spearman Korelasyon Katsayısı & Akılcı İlaç Kullanımı \\
\hline \multirow{2}{*}{ Sağlık Okuryazarlığı } & $\mathbf{r}$ & $0,827^{\star}$ \\
\cline { 2 - 3 } & $\mathbf{p}$ & 0,001 \\
\hline
\end{tabular}

Korelasyon Katsayısı Gücü (r): 0,00-0,25 Çok zayıf; 0,26-0,49

Zayıf; 0,50-0,69 Orta; 0,70-0,89 Yüksek; 0,90-1,00 Çok yüksek * ${ }^{\star}<\mathbf{0 , 0 0 1}$

Tablo 4'de diyabetli bireylerin sağllk ile ilgili özelliklerine göre sağlık okuryazarlığı ve akılcı ilaç kullanım düzeylerinin karşılaştırılması yer almaktadır. Tabloya göre katılımcıların diyabet tanı süresine, başka kronik hastalık durumuna, düzenli doktor kontrolüne, diyabet eğitimi alma ve eğitim gereksinimi durumuna, ilaçlarını düzenli alma ve reçete dışı ilaç kullanma durumuna göre istatistiksel olarak anlamlı farklılık gösterdiği görülmüştür $(\mathrm{p}<0,001)$. Diyabet tanı süresi ile ilgili yapılan ileri analizde tanı süresi $<5$ yıl ve altında olan grubun sağlık okuryazarlığı ve akılcı ilaç kullanım düzeyinin en yüksek olduğu ve tanı süresi artıkça puan ortalamalarının anlamlı şekilde azaldığı belirlenmiştir.

Tablo 5 'te diyabetli bireylerin sağlık okuryazarlığ 1 ve akılcı ilaç kullanımı düzeyleri arasındaki ilişki incelenmiştir. Buna göre diyabetli bireylerde sağlık okuryazarlığı ile akılcı ilaç kullanımı arasında pozitif yönlü ve yüksek düzeyde anlamlı bir ilişki olduğu bulunmuş olup $(r=0,827 ; \mathrm{p}<0,001)$, bireylerin sağlık okuryazarlık düzeyi arttığında akılcı ilaç kullanım düzeyinin de arttığı belirlenmiştir. 


\section{TARTIŞMA}

Diyabetli bir bireyin hastalık yönetimini en doğru, öz-bakımını en iyi şekilde yapabilmesi, diyabetle ilgili yeterli bilgi, beceri ve olumlu tutuma sahip olması için sağlık okuryazarlık düzeyinin yeterli olması gerekmektedir. Sağlık okuryazarlığı, bireylerin hastalık hakkında bilgi edinmesini, kendi başına sağlığına yönelik kararlar alabilmesini sağlayarak sağlık durumunu ve sağlık sonuçlarını olumlu etkilemekte$\operatorname{dir}(11)$. Bu çalışma, diyabetli bireylerde sağlık okuryazarlı̆̆ 1 ve akılcı ilaç kullanımı ilişkisini incelemek amacıyla yapılmıştır. Ülkemizde diyabetli bireylerde bu ilişkinin incelendiği ilk çalışma olması nedeniyle özgünlük anlamında alana katkı sağlayacağı düşünülmektedir.

Çalışma sonucuna göre, diyabetli bireylerin genel sağlık

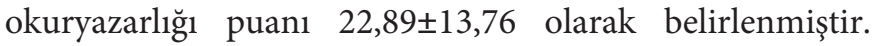
Ölçekten alınan puanlara göre sağlık okuryazarlığının kategorilendirmesi yapıldığında katılımcıların büyük çoğunluğunun $(\% 56,4)$ yetersiz sağlık okuryazarlığına sahip olduğu görülmüştür. Türkiye'deki nüfusun da yaklaşık $\% 65$ 'inin "sorunlu veya yetersiz sağlık okuryazarlığı" kategorisinde olduğu belirlenmiştir (10). Bu sonuçlar ise, sağlık okuryazarlığının ülkemiz için önemli bir sorun olduğunu, toplumun sağlık okuryazarlık düzeyinin artırılmasına yönelik önemli girişimlere gereksinim duyulduğunu göstermektedir.

Diyabetli bireylerin sağlık okuryazarlık düzeyinin belirlenmesine yönelik yapılan çalışma sonuçlarında sağlık okuryazarlığının \%15-40 arasında düşük seviyelerde olduğu bildirilmektedir (40). Brezilya'da tip 2 diyabetli hastaların sağlık okuryazarlık düzeyinin belirlenmesine yönelik yapılan bir çalışmada yetersiz sağlık okuryazarlığ 1 olan bireylerin oranı $\% 43,4$ olarak belirlenmiş olup, yeterli sağlık okuryazarlığına sahip olan bireylerin sağlık sonuçlarının daha iyi olduğu belirlenmiştir (41). Kuveyt'te 359 tip 2 diyabetli bireyin sağlık okuryazarlık düzeyinin belirlenmesine yönelik yapılan bir çalışmada da hastaların \%44,5'inin yetersiz sağlık okuryazarlığına sahip olduğu belirlenmiştir (4). Benzer şekilde yapılan çalışmalarda da diyabetli bireylerin sağlık okuryazarlık düzeylerinin düşük olduğu bildirilmiştir $(17,21)$. Çalışma sonucumuz da literatüre benzer şekilde bulunmuştur.

Araştırmada yaş, cinsiyet, eğitim durumu, medeni durum ve gelir durumuna göre sağlık okuryazarlık düzeyinde istatistiksel olarak anlamlı farklılıklar belirlenmiştir. Erkeklerin, ileri yaştaki diyabetli bireylerin ve evli olmayanların SOY ölçek puanının daha düşük olduğu, eğitim düzeyi ve gelir düzeyi arttıkça puanların da arttığı görülmüştür. Sağlık okuryazarlığının belirlenmesine yönelik yapılan çalışmalarda katılımcıların demografik özellikleri incelendiğinde, genel olarak ileri yaşlarda, kadınlarda, evli olmayanlarda, eğitim durumu ve gelir durumu düşük olan kişilerde sağllk okuryazarlığının daha düşük olduğu belirlenmiştir (42-44). $\mathrm{Bu}$ sonuçlar cinsiyet hariç çalışma sonuçlarımızla benzerdir.

Sağlık okuryazarlığı diyabetli bireylerin sağlığına ilişkin özelliklerinden de etkilenmektedir (18). Çalışmada tanı süresi daha fazla olan ve başka bir kronik hastalığ 1 bulunan diyabetli bireylerin sağlık okuryazarlık düzeyinin daha düşük olduğu görülmüştür. Yapılan benzer çalışmalarda da bireylerin sağlık sonuçlarını etkileyen bu faktörlerin, sağlık okuryazarlık düzeyini azalttı̆̆ı belirlenmiştir $(30,45)$. Genellikle toplumda hastalık süresi arttıkça hastalık yönetiminin daha iyi olacağı, kontrollerini daha düzenli yaptıracağı ve daha fazla bilgiye sahip olunacağı kanısı vardır. Ancak uzun zaman önce diyabet tanısı alan bireylerin hem ileri yaşta olması hem de eşlik eden başka kronik hastalıkların olmasının sağlık okuryazarlık düzeyini etkileyebileceği bildirilmiştir (10). Bu sonuçlar, özellikle ileri yaşta olan diyabetli bireylerin sağlık okuryazarlık düzeylerinin ara ara tanılanmasının ve sonuçlara göre yeni girişimlerin planlanmasının gerekli olduğunu göstermektedir.

Araştırmaya katılan bireylerin $\% 79,1$ oranında büyük çoğunluğunun diyabetle ilgili eğitim gereksinimi olduğu belirlenmiştir. Diyabet eğitimi alanların ise sağlık okuryazarlığ 1 düzeylerinin daha yüksek olduğu bulunmuştur. $\mathrm{Bu}$ çalışmada katılımcıların \%56,4'ünün sağlık okuryazarlık düzeyinin "yetersiz" olduğu düşünüldügünnde konu ile ilgili diyabetli bireylere verilecek eğitimlerin oldukça önemli olduğu sonucuna varılmaktadır. Nitekim sağlık profesyonelleri tarafindan verilecek eğitimlerin diyabetli bireylerin sağlık okuryazarlık düzeyini yükseltebileceği yapılan bir çalışmada belirtilmiştir (46).

Toplumların yaşlanması ve beraberinde kronik hastalıkların artması ile kullanılan ilaç sayıları da artmakta ve bu ilaç kullanımının önümüzdeki on yıllarda daha da fazla artması beklenmektedir. İlaç kullanımındaki bu artış ise insanları ilacı doğru kullanmaya ve karar verme becerilerini geliştirmeye zorlamaktadır. Bu durum ise bireylerin sağlık okuryazarlık düzeylerinin artırılmasının gerekliliğini ortaya koymaktadır. Bu nedenle sağlık okuryazarlığı ve akılcı ilaç kullanımı konusu birlikte ele alınması gereken önemli konulardan olduğu düşünülmektedir (47). İlaçların, bireysel ve toplumsal düzeyde hastalıkların önlenmesi ve mücadelesi konusunda büyük öneme sahip teknolojik ürünler olduğu düşünüldüğünde halk sağlığı açısından bu değerli kaynağın akılcı olarak kullanımı da esas olmalıdır.

Sürekli ilaç kullanmak zorunda olan diyabetli bireylerde de ilaç kullanımı önemli bir konudur. Bu bireylerin günlük diyabet ile ilgili ortalama 2,18 ilaç, reçete başına ise ortalama 5 ilaç kullandığı bildirilmiştir (48). Çalışmada diyabetli 
bireylerin akılcı ilaç kullanımının düşük düzeyde olduğu belirlenmiştir. Bu veriler ıșığında diyabetli bireylerin ilaçlarının akılcı bir şekilde kullanımının önemle üzerinde durulması gereken bir konu olduğu düşünülmektedir.

Çalışmada akılcı ilaç kullanımının bireylerin sosyo-demografik özelliklerinden etkilendiği belirlenmiştir. Kadınların, 48-57 yaş grubunda olanların, eğitim durumunu lise ve üzerinde olarak belirtenlerin, evlilerin ve gelir düzeyi yüksek olanların akılcı ilaç kullanımı düzeyinin istatistiksel olarak anlamlı olduğu belirlenmiştir. Çalışmamıza benzer şekilde akılcı ilaç kullanımına ilişkin diyabet ve/veya hipertansiyonu olan 547 hasta ile yapılan bir çalışma sonucunda evlilerin, çalışanların, eğitim ve gelir durumu yüksek olanların ilaçlarını daha akılcı kullandıkları belirlenmiştir (49). Çalışmada kullanılan Akılcı İlaç Kullanım Ölçeği’nin Türkçe geçerlik güvenirliğinin yapıldığı, 18 yaş ve üzeri 768 hasta ile yapılan çalışma sonucunda da 30 yaş altı, kadınlarda, öğrenim durumunu lise ve üzeri olarak belirtenlerde, gelir durumu iyi olanlarda akılcı ilaç kullanımın daha yüksek olduğu bulunmuştur (39). Yapılan benzer bir çalışmada da benzer şekilde kadınlarda, gençlerde, yüksek gelir düzeyine ve yüksek eğitim seviyesine sahip olanlarda akılcı ilaç kullanımı bilgisinin daha yüksek olduğu bildirilmiştir (50). Bu sonuçlar çalışma sonuçlarımız ile benzerdir.

Akılcı ilaç kullanımı bireylerin sağlığına ilişkin özelliklerinden de etkilenmektedir. Çalışmada tanı süresinin, eşlik eden başka bir kronik hastalık durumunun, düzenli sağlık kontrolüne gidilmesinin ve hastalığa ilişkin eğitim alınmasının akılcı ilaç kullanımını etkilediği görülmüştür. Yapılan bir çalışmada, tanı süresi daha kısa olan, diyabet ile ilgili eğitim alan ve düzenli doktor kontrolüne gidenlerin ilaçlarını daha akılcı kullandıkları belirlenmiştir. Aynı çalışmada katılımcıların \%75,5'inin ilaçlarını düzenli kullandıkları ve hemen hemen tüm katılımciların reçete dişı ilaç kullanmadıkları belirlenmiştir (49). Çalışmamızda da katılımcıların \%85,5'inin ilaçlarını düzenli aldığı ve \% 82,3'sinin reçete dışı ilaç kullanmadığı belirlenmiştir. Bu bireylerde hem sağlık okuryazarlı̆̆ hem de akılcı ilaç kullanım ölçek puanının daha yüksek olduğu bulunmuştur. Diyabet gibi zorunlu olarak sürekli ilaç kullanmak durumunda olan kronik hastaların reçete dışı ilaç kullanımı sonucunda ilaçlar olumsuz etkileşim gösterebilmektedir. Bu durumda ciddi sağlik sorunlarının yaşanması çoğu zaman kaçınılmaz olabilmektedir (48). Bu nedenle reçetesiz ilaç kullanımının ne denli önemli olduğu konusunda bireyler mutlaka uyarılmalıdır.

Ulusal ve uluslararası literatürde diyabetli bireylerde akılcı ilaç kullanım düzeyini geçerlik güvenirlik yapılmış bir ölçek ile değerlendiren herhangi bir çalışmaya rastlanmamıştır. Konu ile ilgili literatürün yeterli olmaması araştırmada akılcı ilaç kullanımı sonuçlarının tartışılmasını kısıtlamış olup, yapılan çalışmalar daha çok diyabetli bireylerin sağlık okuryazarlık düzeyinin tedavi uyumu üzerine etkilerinin değerlendirilmesi amacıyla yapılmıştır. Bu çalışmalardan olan, Shiyanbola ve ark.nın diyabet tanısı almış yaşlılar ile yapmış oldukları çalışma sonucunda sağlık okuryazarlı̆̆ ile tedavi uyumsuzluğu arasında negatif bir ilişki tespit edilmiştir (51). Benzer şekilde yapılan bir çalışmada da düşük sağlık okuryazarlığının tedavi uyumsuzluğuna sebep olduğu, sağlık okuryazarlık seviyesi arttıkça ilaçların reçete talimatlarının daha kolay anlaşıldığı bildirilmiştir (52).

Kronik hastalığı olan 291 yaşlıyı içeren bir çalışmada sağlık okuryazarlığının hastaların ilaç kullanım durumunu etkileyen en önemli faktör olduğu belirlenmiş, çalışma sonucumuza benzer șekilde aralarında pozitif yönlü bir ilişki olduğu bildirilmiştir (53). Bu araştırmamızda da benzer şekilde, sağlık okuryazarlığı ile akılcı ilaç kullanım düzeyleri arasında istatistiksel olarak anlamlı, pozitif yönlü ve yüksek düzeyde bir ilişkinin olduğu belirlenmiştir. Başka bir ifade ile diyabetli bireylerin sağlık okuryazarlık düzeyi arttıkça akılcı ilaç kullanım düzeyinin istatistiksel olarak anlamlı şekilde artmakta olduğu görülmüştür. Sağlık okuryazarlı̆̆ 1 ile reçete talimatlarını, ilaç alım sıklığını, ilaç alım yolunu ve ilaçların endikasyonlarını anlama arasındaki ilişkiyi inceleyen 263 yetişkin diyabetik hasta ile yapılan kesitsel bir çalışma sonucunda da düşük sağlık okuryazarlığına sahip diyabetli bireylerin reçete talimatlarını anlamada zorluk yaşadığı ve ilaçlarını doğru şekilde almadıkları belirlenmiş$\operatorname{tir}(17)$.

Ülkemizde diyabetli bireylerde sağlık okuryazarlığı ve akılcı ilaç kullanımı ilişkisini inceleyen ilk çalışma olması çalışmanın güçlü yönünü oluşturmaktadır. Araştırmada veri toplama aracı olarak kullanılan Akılcı İlaç Kullanım Ölçeği kullanılarak yapılan yerli ya da yabancı literatüre rastlanmamış olması ve bu nedenle araştırma bulgularının tartışılmasının kısıtlanması çalışmanın sınırlılığını oluşturmaktadır.

Araştırma sonuçlarına göre, diyabetli bireylerin sağlık okuryazarlığının ve akılcı ilaç kullanımın yetersiz düzeyde olduğu belirlenmiștir. Her iki durum arasında pozitif yönlü güçlü bir ilişki olduğu sonucuna ulaşılmıştır. Sağlık okuryazarlığ yüksek olan diyabetli bireylerin yeterli bilgi, beceri ve tutuma sahip olması gerekmektedir. Bu şekilde hastalık yönetimini daha iyi yapabildiği, kendi başına sağlığı ile ilgili olumlu karar alabildiği, sürekli kullanmak zorunda oldukları ilaç yönetimini daha doğru yapabildiği ve kendi sağlığı üzerindeki öz-etkililiği daha kolay sağlayabildiği söylenebilir. $\mathrm{Bu}$ nedenle diyabetli bireylerin sağlık okuryazarlık düzeylerinin belirlenmesi ve geliştirilmesi önemlidir. Sağllk okuryazarlık düzeyinin yeterli olması ile sağlık sonuçlarının 
iyileştirilmesinde oldukça önemli olan doğru ilaç kullanımı ve tedavi uyumunun sağlanmasının daha kolay olacağ 1 görülmektedir.

Diyabetli bireylerin bir arada bulunarak etkileşime geçebilecekleri diyabet dernekleri ya da diyabet okullarında özellikle sağlık okuryazarlık düzeyleri düşük olan bireyler belirlenebilir. Onlara uygun eğitim materyalleri kullanılarak bireylerin anlama düzeylerine uygun eğitim programları düzenlenmelidir. Böylece kronik hastalıklar için oldukça önemli olan hastalık yönetimi etkin şekilde sağlanabilir.

\section{Etik Kurul Onayı}

Zonguldak Bülent Ecevit Üniversitesi İnsan Araștırmaları Etik Kurulu'ndan 22.01.2020/723 tarih ve protokol numarası ile gerekli etik kurul onayı alınmıştır.

Çıkar Çatışması

Yazarların beyan edecek herhangi bir çıkar çatışmaları yoktur.

Finansal Destek

Bu çalışmanın yapılabilmesi için herhangi bir finansal destek alınmamıştır.

\section{Yazarların Makaleye Katkı Beyanı}

Çalışma konsepti/Tasarımı: Türkan Akyol Güner, Ayşe Kuzu, Veri toplama: Türkan Akyol Güner, Veri analizi ve yorumlama: Türkan Akyol Güner, Ayşe Kuzu, Yazı taslağı: Türkan Akyol Güner, Taner Bayraktaroğlu, İçeriğin eleştirel incelenmesi: Türkan Akyol Güner, Taner Bayraktaroğlu, Son onay ve sorumluluk: Türkan Akyol Güner, Taner Bayraktaroğlu, Ayşe Kuzu.

Teşekkür

Bu çalışma Zonguldak Kronik Hastalıklar ve Diyabet Derneği'nde yapılmıştır. Çalışmanın veri toplama ve gönüllü katılımcılara ulaşma aşamasında desteğini esirgemeyen dernek başkanına teşekkür ederiz.

\section{KAYNAKLAR}

1. Papadakos JK, Hasan SM, Barnsley J. et al. Health literacy and cancer self management behaviors: A scoping review. Cancer. 2018;124:4202-4210.

2. Poureslami I, Nimmon L, Rootman I, Fitzgerald MJ. Priorities for action: Recommendations from an international roundtable on health literacy and chronic disease management. Health Promot Int. 2017;32:743-754.

3. Van der Heide I, Poureslami I, Mitic W, Shum J, Rootman I, Fitz Gerald JM. Health literacy in chronic disease management: A matter of interaction. J Clin Epidemiol. 2018;102:134-138.

4. Hussein SH, Almajran A, Albatineh AN. Prevalence of health literacy and its correlates among patients with type II diabetes in Kuwait: A population based study. Diabetes Res Clin Pract. 2018;141:118-125.

5. Luckenbaugh AN, Moses KA. The impact of health literacy on urologic oncology care. Urol Oncol. 2019;19:1078-1439.
6. Mackey LM, Doody C, Werner, EL, Fullen B. Self-management skills in chronic disease management: What role does health literacy have? Med Decis Making. 2016;36:741-759.

7. Yilmazel G, Cetinkaya F. Health literacy among schoolteachers in Çorum, Turkey. East Mediterr Health J. 2015;21:598-605.

8. Bazm R, Sardari F. Growth of health literacy research activity in three Middle Eastern countries. BMJ Health Care Inform. 2019;26:e000027.

9. Deniz SS, Özer Ö, Songur C. Effect of health literacy on health perception: An application in individuals at age 65 and older. Soc Work Public Health. 2018;33:85-95.

10. Tanrı̈ver M, Yıldırım H, Ready FND, Cakır B, Akalın E. Turkey Health Literacy Survey 2014; http://www.sagliksen. org.tr. Accessed:13.05.2020.

11. Sorensen K, Pelikan JM, Röthlin F. et al. Health literacy in Europe: Comparative results of the European health literacy survey (HLS-EU). Eur J Public Health. 2015;25:1053-1058.

12. International Diabetes Federation (IDF) Diabetes Atlas. 9th ed. 2019; Erişim:https://www.diabetesatlas.org/. Alıntı: 10.05.2020.

13. International Diabetes Federation (IDF) Diabetes Atlas, 1 th ed. 2000; Erişim:http://www.idf.org/webdata/docs/Diabetes\%20 Atlas\%20Executive \%20Summary.pdf. Alınt1:10.05.2020.

14. Satman I, Omer B, Tutuncu Y, Kalaca S, Gedik S, Dinccag N, Karsidag K, Genc S, Telci A, Canbaz B, Turker F, Yilmaz T, Cakir B, Tuomilehto J. TURDEP-II Study Group. Twelve-year trends in the prevalence and risk factors of diabetes and prediabetes in Turkish adults. European Journal of Epidemiology. 2013;28:169-180

15. American Diabetes Association. Standards of medical care in diabetes 2013. Diabetes Care. 2013;36:11-66.

16. American Diabetes Association. Microvascular complications and foot care. Diabetes Care. 2016;39:72-80.

17. Singh S, Acharya SD, Kamath A, Ullal SD, Urval RP. Health literacy status and understanding of the prescription instructions in diabetic patients. J Diabetes Res. 2018:1-5.

18. Sorensen K, Van Den Broucke S, Fullam J, Doyle G, Pelikan J, Slonska Z, (HLS EU) Consortium Health Literacy Project European. Health literacy and public health: A systematic review and integration of definitions and models. BMC Public Health. 2012;12:1-13.

19. Nutbeam D. Health promotion glossary. Health Promotion International. 1998;13:349-364.

20. Centers for Disease Control and Prevention (CDC). Learn about health literacy. Erişim: http://www.cdc.gov/ healthliteracy/learn/index. html. Alınt1:18.05.2020.

21. İlhan N, Telli S, Temel B, Aștı T. Health literacy and diabetes self-care in individuals with type 2 diabetes in Turkey. Prim Care Diab. 2020;S1751-9918(20)30221-7.

22. Fernández Silva MJ, Alonso González A, González Pérez E, Gestal Otero JJ, Díaz Grávalos GJ. Health literacy in patients with type 2 diabetes: A crosssectional study using the HLS-EU-Q47 questionnaire. Semergen. 2019;45:30-36. 
23. Niknami M, Mirbalouchzehi A, Zareban I, Kalkalinia E, Rikhtgarha G, Hosseinzadeh H. Association of health literacy with type 2 diabetes mellitus self management and clinical outcomes within the primary care setting of Iran. Aust J Prim Health. 2018;24:162-170.

24. Bohanny W, Wu SF, Liu CY, Yeh SH, Tsay SL, Wang TJ. Health literacy, self-efficacy, and self-care behaviors in patients with type 2 diabetes mellitus. J Am Assoc Nurse Pract. 2013;25:495502.

25. Bailey SC, Brega AG, Crutchfield TM, Elasy T, Herr H, Kaphingst K, et al. Update on health literacy and diabetes. Diabetes Educ. 2014;40:581-604.

26. Al Sayah F, Majumdar SR, Williams B, Robertson S, Johnson JA. Health literacy and health outcomes in diabetes: A systematic review. J Gen Intern Med. 2013;28:444-452.

27. Dahal PK, Hosseinzadeh H. Association of health literacy and diabetes selfmanagement: A systematic review. Aust J Prim Health. 2019;25:526-533.

28. Türkoglu C. Analyzing the relationship between health literacy and self-care ability level: The case of Isparta, master thesis. Süleyman Demirel University Institute of Social Sciences, 2016, Isparta.

29. Hussain N, Said Amira SA, Khan Z. Influence of health literacy on medication adherence among elderly females with type 2 diabetes in Pakistan. Int Q Community Health Educ. 2020;41(1):35-44.

30. Özonuk E, Yilmaz M. Relationship between health literacy and compliance with the treatment among individuals with type 2 diabetes mellitus. J Educ Res Nurs. 2019;16:96-103.

31. Ho PM, Bryson CL, Rumsfeld JS. Medication adherence: Its importance in cardiovascular outcomes. Circulation. 2009;119:3028-3035.

32. World Health Organization (WHO), Promoting rational use of medicines: Core components. WHO Policy Perspectives on Medicines no5. WHO, 2002; WHO/EDM/2002.3.Geneva, Alıntı: 10.05.2020.

33. World Health Organization WHO 2016; Erişim:http://www. who.int/medicines/areas/rational_use/en/. Alıntı: 10.06.2020.

34. İlhan MN, Aydemir Ö, Çakır M, Aycan S. Akılcı olmayan ilaç kullanım davranışları: Ankara'da üç ilçe örneği. Türkiye Halk Sağlı̆̆1 Dergisi. 2014;12:188-200.

35. Uchenna O, Ijeoma E, Pauline E, Sylvester O. Contributory factors to diabetes dietary regimen NonAdherence in adults with diabetes. World Academy of Science, Engineering and Technology. 2010;45:735-742.

36. Jin J, Sklar GE, Oh VMS, Li SC. Factors affecting therapeutic compliance: A review from the patient's perspective. Therapeutics and Clinical Risk Management. 2008;4:269-286.

37. Türkiye Diyabet Vakfı. 2010-2020 Ulusal Diyabet Stratejisi Sonuç Dokümanı. Erişim:http://www.tsn.org.tr/folders/file/ Diyabet_2020_Sonuc_Dokumani.pdf. Alıntı: 05.05.2020.

38. Okyay P, Abacıgil, F. Türkiye Sağlık Okuryazarlığı Ölçekleri, Güvenilirlik ve Geçerlilik Çalışması. (1. Baskı). Ankara: Sağlık Bakanlığı Yayın No:1025, 2016;77-80.
39. Demirtaş Z, Dağtekin G, Sağlan R, Alaiye M, Önsüz MF, Işıklı $\mathrm{B}$, et al. Akılcı İlaç Kullanımı Ölçeği Geçerlilik ve Güvenilirliği. ESTÜDAM Halk Sağlığı Dergisi. 2018;3:37-46.

40. Cavanaugh KL. Health literacy in diabetes care: Explanation, evidence and equipment. Diabetes Manag (Lond). 2011;1:191199.

41. Souza JG, Apolinario D, Magaldi RM, Busse AL, Campora F, Jacob-Filho W. Functional health literacy and glycaemic control in older adults with type 2 diabetes: A cross-sectional study. BMJ Open. 2014;4:e004180.

42. Cho YI, Lee SYD, Arozullah AM, Crittenden KS. Effects of health literacy on health status and health service utilization amongst the elderly. Soc Sci Med. 2008;66:1809-1816.

43. Morris NS, MacLean CD, Littenberg B. Change in Health literacy over 2 years in older adults with diabetes. Diabetes Educ. 2013;39:63846.

44. Ussher M, Ibrahim RS, Reid F, Swah A, Rowlands G. Psychosocial correlates of health literacy among older patients with coronary heart disease. J Health Commun. 2010;15:788804.

45. Inoue M, Takahashi M, Kai I. Impact of communicative and critical health literacy on understanding of diabetes care and self-efficacy in diabetes management: Across-sectional study of primary care in Japan. BMC Fam Pract. 2013;14:1-9.

46. Watts SA, Stevenson C, Adams M. Improving health literacy in patients with diabetes. Nursing. 2017;47:24-31.

47. Abacıgil F, Gürsoy Turan S, Adana F, Okyay P, Demirci B. Rational use of drugs among inpatients and its association with health literacy. Meandros Med Dent J. 2019;20:64-73.

48. Singh D, Sawlani K K, Chaudhary S C, Kumar N, Sachan AK. Drug utilization study of drugs used in treatment of diabetes mellitus in medicine OPD of a tertiary care hospital in northern India. IP Int J Compr Adv Pharmacol. 2019;4:120-125.

49. Pereira Mendes LV, Luiza VL, Campos Rodrigues M. Rational use of medicines by individuals with diabetes mellitus and arterial hypertension in the municipality of Rio De Janeiro, Brazil. Cien Saude Colet. 2014;19:1673-1684.

50. Bian C, Xu S, Wang H, Li N, Wu J, Zhao Y et al. A study on the application of the information-motivation-behavioral skills (IMB) model on rational drug use behavior among second-level hospital outpatients in Anhui, China. Plos One. 2015; 10:e0135782.

51. Shiyanbola OO, Unni E, Huang YM, Lanier C. The association of health literacy with illness perceptions, medication beliefs, and medication adherence among individuals with type 2 diabetes. Res Social Adm Pharm. 2018;14:824-830.

52. Fan JH, Lyons SA, Goodman MS, Blanchard MS, Kaphingst KA. Relationship between health literacy and unintentional and intentional medication nonadherence in medically underserved patients with type 2 diabetes. Diabetes Educ. 2016;42:199-208.

53. Lee YM, Yu HY, You, Son YJ. Impact of health literacy on medication adherence in older people with chronic diseases. Collegian. 2017;24:11-18. 